\title{
Continuity of hegemonic power? The case of modern plantation labour in North Sumatra, Indonesia
}

See final draft here: https://www.tandfonline.com/doi/abs/10.1080/13547860.2020.1773620

Susan de Groot Heupner (2020): Continuity of hegemonic power? The case of modern plantation labour in North Sumatra, Indonesia, Journal of the Asia Pacific Economy, pp. 540-541.

\begin{abstract}
Although it has been more than 150 years since the emergence of the plantation, labour in the democratic context of post-1998 Indonesia remains subject to similar forms of suppression. Following the distinct social and political trajectory of North Sumatra, this paper provides an explanatory analysis of the interrelation between historical hegemonic social relations and the mobility of labour in modern palm oil plantations. Following welldocumented accounts of colonial plantation practices, this paper empirically examines whether it is plausible to argue that histor- ical forms of subordination remain relevant to the political mobil- ity of plantation labour. To guide the evaluation, I will look at the existence of historical practices of labour control on the one hand and conditions of democratic reform and structural change on the other. I argue that the modern plantation is constitutive of historically inscribed social relations that function to keep intact colonial and authoritarian structures.
\end{abstract}

\section{KEYWORDS}

Labour; plantation; mobility; palm oil; Indonesia

\section{Introduction}

Despite the significance of palm oil production for the global vegetable oil market and the Indonesian economy, there have been relatively few empirical studies to understand the current labour conditions from a historical perspective. While the issue of labour conditions is taken into consideration in the corporate and institutional push for sustainable approaches to palm oil production, little attention is given to understand and address its structural foundations. In response to the deficit in analysis and policy, this paper aims to find out whether historically embedded hegemonic relations remain relevant to explain the current state of labour (im)mobility. By abstracting what Jan Breman $(2015,201)$ conceptualises the 'colonial constant' it becomes able to perceive the contradictory parallels between the evolutionary change of the political and economic, and the durability of an established regime of social surveillance, discipline and punishment.

Following from the central thesis of prominent scholars in colonial labour studies such as Breman, John Thomas Dunlop and Ann Laura Stoler, I will explore the continuity of historically documented practices of labour suppression. On the basis of ethnographic research findings, I will examine the prevalence of coercive social relations, informal forces and mechanisms of control, and the exercise of structural punishment in five palm oil plantations in North Sumatra. In the same vein, I will assess the relevance of two decades of democratisation by looking at the degree to which plantations respect international labour 
standards and freedom of association. By perceiving these two questions in parallel, I am able to confirm the continuity of historically established social relations and the resilience of the colonial regime of production.

The first section of the paper presents a brief overview of the positionality of labour from the emergence of the plantation system in the early 19th century up until the postindependence period of the second half of the 20th century. The following section will apply the concepts 'ruin' and 'ruination' to examine the evolutionary trajectory of the plantation system and evaluate its relevance to empirical findings. In particular, the focus of analysis is on the correlation between trade union activity and labour violations. This methodological approach is useful to analyse the tension between the colonial constants - the constant features of the colonial production regime - and forces of democratic and liberal reform. The final section explores the consequences of the colonial constant of labour subordination for the mobility of trade unions and agency of workers.

As one of the most economically significant plantation crops in Indonesia, palm oil provides an interesting case study on the effects of democratisation and labour agency. To collect the necessary empirical data for this research I spent a total of four months in North Sumatra between 2014 and 2016. Together with "SERBUNDO" (Serikat Buruh Perkebunan Indonesia), the most prominent independent trade union in the national palm oil industry, I was able to visit five plantations and join trade union activities. The research findings derive from meetings and interviews with unionised workers, engagement in strategic workshops and group discussions with local and national trade union organisers (both independent and corporate-affiliated), formal investigation of labour conditions during and after plantation working hours, and interaction between trade union organisers and informal and formal security forces. During the latter I witnessed firsthand the use of intimidation strat- egies to suppress labour agency and trade union activity. Because we visited the plantations for weeks on end, I often resided with plantation workers and local trade union organisers.

To protect the safety of workers, the fieldwork data includes unionised workers only, who are those affiliated with the independent trade union. Without the assistance of the independent trade union visiting the plantations and meeting the workers would have been difficult, if not impossible. These two necessities in themselves are important findings. For verification purposes, further information is obtained from meetings with current members of former paramilitary organisations, expert scholars, national think-tank on industry and labour, prominent social activists, plantation management, NGOs and the international sustainable palm oil certification body (RSPO). The historical account is based on primary documentation from the state archives of the Netherlands as well as an extensive body of literature on the origins and development of plantation labour in Indonesia and North Sumatra more specifically.

\section{The establishment of the plantation}

The foundation of the plantation as a social reality traces back to the 19th century and the formalisation of large-scale cultivation of a single crop under Dutch colonial rule. Parallel to the acceleration of international trade in the mid-19th century, large-scale plantations were developed to meet the demands of core products such as coffee and tobacco as well as other traditional plantation commodities (Jonker and Sluyterman 2000). Accompanied by 
economic reform, a legal framework of ownership was established in favour of Dutch trade and investment in order to encourage and support the large-scale development of commodity estates (Stoler 1986). Backed by colonial merchants, acquisitions of smaller plantations became part and parcel of the liberalisation and commercialisation of commodity production and international trade (Breman 1989).

In 1902, the Dutch Attorney J. van den Brand was the first to accuse plantation companies of labour abuse (Kloosterboer 1960). These accusations led to the forma- tion of the Labor Inspection Service of the Outer Provinces that called for the protec- tion of unskilled workers, also known as 'coolies', and the provision of facilities in the plantation zone (Breman 1989). From the outset, the demand for provisions was guided by the interests of the colonial government and the plantation companies. The shortage of labour in Sumatra made it necessary for companies to recruit coolies from elsewhere, and the provisions were a financial investment in a labour force prone to bondage and forced labour (Stoler 1986). With the support of government and local rulers, power became concentrated in the hands of the companies who by way of concerted action ensured labour was controlled across all plantations (Breman 1989).

By the end of the first decade of the 20th century, a disciplinary and coercive labour system had become firmly established. By contract, coolies were confined to the plantation geographical boundaries and, as stated by Breman (1989, 131), 'usually had no alternative but to resign themselves to a labour regime that deprived them of any mobility'. Although it may appear the labour system was driven entirely by direct coercion, it was the 'informal mechanisms' that were most significant to the system of labour control (Breman 1989). Coolies were subjected to harsh treatment from low level bosses, known as the foreman, whose function it was to ensure obedience and submission to authority, and keep workers in a perpetual state of fear for punishment. For example, whenever imposed production targets were not met, coolies were either forced to work extended hours, demoted or threatened with dismissal. Coolies who proved reliable were promoted to the position of foreman or the higher-ranking assistant; a desirable position for most. With workers themselves intrinsic to the mechanism of discipline and punishment, companies were able to maximise the rate of exploitation while simultaneously minimising the risk of labour resistance (Breman1989; Stoler 1986).

Given the repressive nature of this plantation labour regime, collective labour action was a rare phenomenon in the first half of the 20th century. However, absence of collective opposition is not to assume coolies were entirely passive. On the contrary, written correspondence between the Dutch government and local colonial authorities is evidence of the concerns about the possibility of collective action. Yet it was not until 1942 when the Japanese invasion led to the dispossession and transfer of property that workers were able to organise and challenge the inherent features of the plantation regime (Breman 1989; Ford 2009; Stoler 1986). In what follows, the transfer of ownership from one ruling elite to another and the simultaneous inde- pendence struggles repositioned workers in direct opposition to the new property owners (Kahin, 1999).

During the early stages of post-independence, trade unions took on an important role in the nationalist movement advanced by Sukarno. In 1962, the most dominant trade union, the Central Organisation of Indonesian Trade Unions (Sentral Organisasi Buruh Seluruh Indonesia, SOBSI) counted 3.2 million members, with the greatest number of members being in the plantation sector (Ford 2009). This was reversed not long after when the 1965 
coup attempt set in motion the demise of Sukarno's reign and marked the end of the emancipation of labour for decades to come (Hadiz 2003; Aspinall and Fealy 2010). In the period between 1965 and 1966 the military command of General Suharto led to the killing of hundreds of thousands of adversaries, among which trade unionists were a large majority (Cribb 2001). In North Sumatra, the army utilised local militias to take control of the killings, which, by means of arms supplies, training and (forceful) recruitment, laid the foundations for the social structuration of informal mechanisms of power (Cribb 2001). In 1967, the authoritarian New Order regime was established that determined Indonesian pol- itics and the positionality of labour for the subsequent thirty-two years (Aspinall and Fealy 2010; Hadiz and Robison 2013; Lane 2009).

\section{The colonial and new order legacy}

In her comprehensive analysis on imperial and postcolonial regimes, Stoler (2008) examines the remains of historical formations and the extent to which 'imperial debris' marks current structures of vulnerability and domination. Stoler (2008) applies the metaphorical conceptions of 'ruins' and 'ruination' to describe the processes of destruction, transformation and renewal from one regime to another. Despite processes of destruction, transformation and renewal in Indonesia over the last century in particular, the plantation appears neither in ruin nor in the process of ruination. Whereas other sections of the economy, such as the manufacturing industry, has undergone democratic labour reform, the plantation appears to be immune to colonial and authoritarian decay. As Stoler (1986) observes in a separate study on the development of Sumatra's plantation belt from 1870 to the late 20th century, the plantation appears to be arranged to permanently facilitate labour suppressive practices.

The fieldwork conducted for this paper exposes an almost identical reality to the historical accounts presented by Breman (1989), Stoler (1986), Tornquist (2004) and the like. The material reality of the plantation, such as the location of barracks, lack of infrastructure and inadequacy of services, reflects the geographical design institu- tionalised under colonial rule. Whereas in the early stages of the plantation a disciplinary system of coercion and violence was deemed necessary to ensure an ample labour supply, companies in the current context have a pool of cheap labour at their disposal. This variance in the availability of labour would suggest that a system of discipline and punishment is no longer a necessary requisite for economic sustainability. In his reflection of an evaluation report published in 1904, Breman (1989) refers to mechanisms of intimidation and corporate punishment as having formed 'successive gradations of a more general pattern in the uncontrolled exercise of power which characterized relations between planters and coolies' (Breman 1989; Pelzer 1978). The current-day social and political reality of plantation workers strongly suggests colonial patterns of discipline and punishment have become fully institutionalised.

In the spatial confines of the plantation, suppression is more easily practiced and disguised than in other industries. In the context of North Sumatra this is further facilitated by the established alliance between plantation companies and former paramilitary organisations (Hadiz 2003). Due to their central position in local politics, these militias have strong connections with local authorities, such as community and religious leaders. Either by way of extortion or intimidation, this social network operates to condemn labour mobility, such as 
protests and legal action, in the broader community (Caraway and Ford, 2014). Based on the narratives of trade unionists, ulama's (religious teacher) and school teachers, both inside and outside the plantation, receive strict guidance on how to educate on matters of labour discipline and resistance. This network of informal relations bears resemblance to the social and political order that facilitated the regional crackdown on labour and the mass killings of 1965-1966. With reference to North Sumatra, Vedi Hadiz (2003) argues that local politics characterised by violence and money are not 'symptomatic of a painfully consolidating or maturing (liberal) democracy, but fundamental instead to the logic of a 'something else' already more or less entrenched' (Hadiz 2003, 121). This 'something else' can be interpreted as the web of social relations between informal and formal authorities that, despite democratic reform and the decentralisation of power, is proven difficult to disintegrate. This is the case all the more for the plantation system that is, by design, spatially isolated and thus more capable to endure democratic transformations.

\section{The positionality of labour}

In their reflection on the positionality of labour in global production networks, Andrew Cumbers, Nativel, and Routledge (2008) acknowledge the lack of research that, as a premise, postulates labour as an effective and competent constituent of the global political economy. Instead, labour is often represented as a passive actor not equipped with the necessary resources, skills and knowledge to organise and generate reform. Studies on global production networks situate state and corporate actors at the forefront of international governance and institutional reform, which, both in practice and in theory, tends to contribute to the lack of recognition of labour as an active and integral constituent of the global economic system (Cumbers, Nativel, and Routledge 2008). In the context of the plantation system, it is particularly true that labour is underacknowledged, under-resourced and underskilled. While this is descriptive of the reality of labour in the palm oil plantations of North Sumatra, labour is by no means passive, ineffective or incompetent. Rather, this perceived passivity, ineffectiveness and incompetence is rooted in the embeddedness of social relations that constitute the plantation system and functions to situate labour on the periphery.

In modern times of global production, market initiatives are deemed more constructive, effective and functional than the modus operandi of trade unions. In many cases, the latter is criticised for adhering to outdated theories that can no longer be considered applicable to the modern global economy. To support the global economic status quo, independent trade unions are widely repressed in the global south by state and corporate mechanisms (Cumbers, Nativel, and Routledge 2008). Here, the stress on 'independent' is to emphasise its variance with state-and corporate-affiliated trade unions whose primary undertaking is to seek power and wealth through political and economic alliances (Ford 2009). Interviews with labour experts and NGOs indicate that a primary objective of independent trade unions in the post-1998 context is to immobilise the corrupt trade unions that inherently function to safeguard state and corporate interests. Concerns raised by unionised workers about the leadership of the independent trade union and their relative position of power points to an engrained distrust towards trade unions in general. For instance, the mode of transport used by the trade union leadership to visit the plantations has been questioned on numerous occasions in conversations with and between unionised 
workers. To address this matter of distrust, the trade union regularly organises information sessions to inform workers on the actual representative role of trade unions and the importance of workers' active participation.

In Indonesia, the reforms prompted by Sukarno's post-independence 'Guided Democracy' in the 1950s enabled companies and the state, with considerable support of oligarchical structures, to control and suppress the activity of trade unions (Hasibuan 1968; Lane 2009). Under the leadership of General Suharto, hundreds of thousands of communists, trade unionists, members of the Indonesian Communist Party (Partai Komunis Indonesia, PKI) and the Indonesian Nationalist Party (Partai Nasional Indonesia, PNI), leftist civil society groups, scholars and professionals were murdered, with an indefinite number more detained and tortured (Aspinall 2013; Aspinall and Fealy 2010). In the attempt to further the anti-communist agenda, left-oriented trade unions were banned, and by the 1970s, the few conservative trade unions remaining were formed under one single federation, the All Indonesia Labour Federation in 1973 (Federasi Buruh Seluruh Indonesia, FBSI), later to be restructured as the All-Indonesia Workers' Union (Serikat Pekerja Seluruh Indonesia, SPSI). Although a trade union in form, the structure and practice of FBSI served primarily to accommodate corporate and state interests, with officials from Suharto's political party, 'Golkar', taking on central and regional leadership (Hadiz 2003).

As a remnant of the New Order, all palm oil plantation workers are by contract enforced membership to SPSI and withdrawal requires written approval from SPSI or plantation management. The trade union has ample documentation that confirms the correlation between requesting formal withdrawal and the (immediate) dismissal, demotion or relocation of workers and family members. As of 2017, SERBUNDO is the only active independent palm oil trade union in North Sumatra and has recently expanded to other parts of Sumatra and Kalimantan. Official withdrawal from SPSI is a precondition for membership to SERBUNDO, and owing to the deliberate interfer- ence by management and direct threats from foremen, workers often decide to retract their initial request for SPSI resignation. Thus, workers are compelled into corrupt trade unions and prevented from participating in political bargaining. Based on detailed chronological documentation of a recent case, the governmental Social Services, Manpower and Transmigration district office stalled the process of resignation for more than three months, during which the workers were faced with frequent intimidation and punishment. Primary documentation from the local trade union office states that 44 of the total of 229 unionised workers withdrew membership from SERBUNDO within two months. Group meetings with some of these former members confirms that the reasoning for their withdrawal is based on repeated instances of threats from foremen and low-ranking assistants, and subsequent fear of punishment. This is a typical case of trade union suppression in the context of the plantation, and a clear demonstration of the multilayered structure of social relations that serves to immobilise labour.

\section{Institutional reform and labour agency}

In his analysis of industrial relations, Dunlop examines the interrelations between regulatory processes and functional imperatives of the economic system on the one hand, and commonalities of interests among actors on the other (Dunlop 1958; Poole1981). Following 
Dunlop's framework, power arrangements can be perceived as being structured according to common interests, a process that necessitates the exclusion of actors whose interests are considered in opposition (Dunlop 1958; Poole 1981). In this view, plantation labour is strategically situated on the periphery from the outset to help institutionalise hegemonic power relations, hence the suppression of actors that aim to reposition labour as a more active constituent of the local plantation economy (Li 2014, 2015). Dunlop's conceptual framework of industrial relations separates the theoretical function of labour from empirical analysis on the agency of labour. This separation enables a more accurate analysis of the function of plantation labour in relation to the plantation economy, and the agency of labour in relation to local social and political dynamics.

Soon after the formation of the Labor Inspection Service of the Outer Province, plantation companies found ways to evade and manipulate labour inspections (Breman 1989). The ease with which companies could control labour inspections and fend off regulations suggests the close interrelation between government and industry. Based on conversations with NGOs, trade unionists and unionised workers, labour inspections are often manipulated by restricting the movement of auditors to the areas of the plantation closest to the entry, which is where the original premises of the colonial authorities are located, the upper standard barracks and facilities, such as the school, the place for worship, and the medical centre. Furthermore, auditors rely on interviews with pre-selected workers who are often chosen on the basis of their compliance. As trade unionists explain, prior to the audit inspections foremen are instructed to intimidate low-level workers to prevent the disclosure of oppressive labour realities. Moreover, third-party auditors have been accused of corruption and cherry-picking fieldwork data according to the interest of those who would be held accountable for violations of labour rights. Seeing the overlapping economic interests between government and industry, accusations of deliberate government negligence is not too far-fetched. Palm oil is the most popular vegetable oil in the world today, and within the context of the global competitive commodity market, low labour costs are in both economic and political interests of states and investors. From this point of view, the underlying rationale of the Labor Inspection Service of the Outer Province of the early 20th century is simi- lar to the accreditation institutions that drive the global sustainable palm oil industry today.

At present, Indonesia has ratified 19 Conventions of the International Labour Organization (ILO), including nine fundamental Conventions. These fundamental Conventions include the 1949 Right to Organise and Collective Bargaining Convention and the 1998 Freedom of Association and Protection of the Right to Organise Convention. As primary fieldwork data indicates, ratification of ILO Conventions is not a guarantee that such fundamental rights and principles are respected at the ground level. Both primary and secondary data strongly suggests institutional reform has not presented workers the guarantee that fundamental rights, such as freedom of association and collective bargaining, are complied with. Despite newly imposed institutional and legal regulations, localised systems of power largely interfere with top-down efforts to provide the necessary space for labour to organise. In addition to the ILO, national and international palm oil accreditation institutions, such as the Indonesian Sustainable Palm Oil System (ISPO) and the Roundtable on Sustainable Palm Oil (RSPO), include the right to form and join trade unions in their principles and criteria. Partly due to inadequacies of the labour inspection and complaint mechanisms, the RSPO and the ISPO have thus far not been able to ensure 
corporate compliance in the plantations included in this research.

Following discussion on international law and forced labour, Jean Allain $(2015,345)$ reinstates the need for regular labour inspections to 'distance labour from exploitation'. Similarly, Suzanne Miers (2003) suggests in spaces where there is no functional system of inspection it is more likely for exploitative practices to evolve into structural suppression. Other than the required audit that is part of sustainable palm oil certification due every year or less frequently depending on the track record of the plantation company, there is no formal system of labour inspection. While the independent trade union attempts to fill this gap and actively challenges issues of labour abuse and exploitation, the complexity of local power dynamics is generally the cause of interference with jurisdictional processes. For example, according to trade union leaders, the office of SERBUNDO in the Sumatran capital city of Medan is regularly targeted by militias and police to intimidate the leadership, generally whilst occupied with legal cases or protest activities.

Both on the basis of field observations and primary documentation, such as payslips, official letters, newspaper articles and photographs, without the presence of strong trade union representation, workers are in an exceptionally vulnerable position to advocate their case, some of which resulting in preventable deaths. Based on more than twenty years of anthropological research in plantations in Sulawesi, Tania Murray Li $(2017,1171)$ remarks '[e]ffective regulation of plantations by workers is a necessary counterpart to strong legal rights, but currently both elements are lacking'. This being the case, workers are compelled to calculate the added benefits against the risks, and more often than not, choose not to raise their case. What follows is a dis- torted representation of the reality of labour, which is problematic for two reasons. For one, it does not bring to light the systemic nature of labour rights violations, hence producing top-down policies that do not target the root of the problem. And second, while the demand for sustainable palm oil is growing, labour is further removed from the discourse which has resulted in the export of "sustainable" palm oil from plantations that contravene international labour rights (Bissonnette 2012).

Looking at both historical and contemporary plantation realities, institutional topdown approaches have been largely unable to penetrate into the distinct labour regime of the plantation. Moving forward, there is a need for governments, institutions, NGOs and trade unions to pragmatically acknowledge that the plantation system is historically designed to withstand top-down approaches. Based on primary accounts from local trade union leaders, the modus operandi of palm oil and labour institutions has frequently led to aggressive suppression of trade union activity and further exacerbation of labour conditions. Hence, on the basis of this correlation, there appears to be a substantial link between hierarchical power structures and coercive mechanisms that historically have not equipped labour the necessary means to withstand corporate pressure. Thus, labour violations are the symptoms of hierarchical power relations and not the disease itself; a conviction that appears in conflict with prevailing symptomatic top-down strategies. A common view on the weakness of top-down labour approaches is clearly expressed by a trade unionist in Cumbers, Nativel, and Routledge (2008, 381), who says:

Because today it is obviously companies like BP and TOTAL that control paramilitary groups since security is not being controlled by the state-something which ought to be one of its primary tasks - but it is the petrol companies that pay the paramilitary groups themselves. So 
you can write all the codes of conducts you like but you are not getting to the heart of the problem.

This statement raises questions on the interrelation between power and interests of different hegemonic actors, particularly between companies, states and (former) paramilitary organisations. It is, for example, for economic and political reasons not likely for the Indonesian state to voluntarily impose strict regulations on plantation corporations to comply with labour standards. Similarly, it is unlikely for plantation companies to voluntarily abandon the alliance with local militias that ensures labour compliance and economic security. Because in the current context plantation companies appear to operate according to international labour standards, there is hardly any evidence of pressure on the state to reconstruct the prevailing social and political arrangements at the local level.

\section{Structural immobilisation}

In the context of North Sumatra, labour mobility has been a constitutive component of the plantation system. Whether due to a scarcity of labour, like in colonial times, or to a surplus of casual labour that is the case currently, plantations have historically attracted workers from across and beyond the peninsula (Ford 2009). For the purpose of this paper, the focus is not on the actual mobility of labour, but rather on the structural realities that function to mobilise and immobilise labour. In other words, the point of interest here is to lay out the conditions of (im)possibility for plantation labour to display mobility and agency in the social setting of North Sumatra. With that in mind, emphasis is on the material conditions that sustain colonial and authoritarian social relations that function to control the mobility and agency of labour.

With the exception of casual labour, contracted workers are entirely dependent on the social welfare system of the company. This social welfare system originates from colonial times and includes housing, electricity, water, access to supplies, education for children, medical service and an allowance for rice, all of which with a fluctuating level of quantity and quality. This is determined by the worker's ability to reach targets, compliance to rules and regulations, non-participation in trade union activities and employment history. Workers who, for instance, request to receive a payslip have often been relocated to divisions with lesser living standards and received reductions in allowances and rations. In PT. Rimba Mujur Mahkota, workers in the most remote division do not have safe access to fresh water, are subjected to variable time restric- tions on the use of electricity and reside in leaking barracks.

Workers are allocated to different divisions, each of which are distinct from one another in terms of the quality of, and access to, infrastructure. Based on interviews and primary observations in PT. Rimba Mujur Mahkota, the division with the highest trade union representation is also the most geographically remote division. In this part of the plantation, workers need to travel far distances on dirt and swampy roads to access primary facilities. Visual and written documentation from the local trade union office points to preventable instances of death in remote locations where work- ers were forced to obtain water from crocodile-infested waters, repair power lines and were unable to reach the medical centre in due time for childbirth. From meetings between unionised workers and trade unionists it appears the condition of these remote divisions is of such low quality as a result of trade union participation, and not vice versa. Not only does this demonstrate the inseparability of 
the social welfare regime to the punishment system, it also emphasises the high degree of dependency forced upon workers for their subsistence.

As the listed penalties on payslips collected from workers at PT. Rimba Mujur Mahkota reveals, it is recurrent corporate practice to impose unreasonable production targets that 'legitimises' sanctions and other forms of punishment if not being met. These targets not only demand long working days of more than twelve consecutive hours, but also forces workers to outsource part of their labour to informal casual workers and family members, including children, in order to meet the imposed level of productivity. When outsourcing to casual workers this involves paid labour, which means workers are deprived of part of their salary in order to give payment to the additional worker. Because this is an informal arrangement, the deduction is not evident in official salary documentation such as contracts and payslips. In the case of family members, this is generally unpaid labour. In both instances, the quantitative rate of exploitation is increased given the increase in the rate of productivity and the invariability in remuneration. Even despite the efforts of workers to increase their labour productivity, official documentation on labour performance discloses that workers often remain unsuccessful in reaching production targets. Thus, the actual income of the worker is usually substantially lower than the contract salary, not only due to sanctions and outsourcing of labour, but also to fabricated charges, such as the droppings of palm oil kernels.

The purpose of sanctions and wage reductions is to be understood in relation to other forms of punishment, such as the relocation of workers to other divisions within the plantation or plantations located elsewhere. As a consequence of the very intricacies that form this system of discipline and punishment, workers are largely dependent on the plantation company for their subsistence. From the documentation and narratives of unionised workers in the plantations included in this research, the actual income of workers is generally below the subsistence wage. In turn, workers are forced into greater dependency on the social welfare system of the plantation. Whilst this may not be evident explicitly, the corporate social welfare system is an inherent feature of the system of discipline and punishment.

The informal mechanisms of power distinctive to North Sumatra has contributed significantly to the structuration of labour suppression. The corporate alliance with different local militias is clearly visible from the signposts situated along the planta- tion borders. In the local towns and capital of Medan, representatives of paramilitary organisations and areas of control can be easily identified by their typical emblems, uniforms, banners and flags. The independent trade union has documented numerous occasions of intimidation and harassment from these militias directed towards union- ised workers and trade union organisers. It should be noted that the most prominent paramilitary organisations currently active in North Sumatra, such as Pancasila Youth (Pemuda Pancasila), took a major role in the killings of 1965-1966. Interestingly, when raising the topic of militias, trade unionists and workers did not voice concerns about the historical events and prevailing power relations in the local regions. This lack of concern could point to an embedded normality of local social and political dynamics, and whilst not stated as such, it is not entirely unthinkable that the power of militias has a debilitating effect on the political mobility and agency of workers.

\section{Conclusion}


This study has examined the durability of the plantation labour regime by exploring the plausibility of the continuity of historical hegemonic relations. I have raised the question of continuity and resilience to empirically assess whether the 'colonial constant' remains relevant for our understanding of the political mobility of plantation labour in North Sumatra today. Research findings found the prevalence of coercive relations, informal mechanisms of control and structural punishment, and the relative absence of democratic and liberal labour reform. By viewing the plantation as a historically designed social system, this paper has been able to demonstrate the resilience of historical forms of subordination and the potential of the plantation system to withstand more than a century of political transformation, destruction and renewal. Rather than seeing labour as a passive constituent of the plantation system, this paper has shown the correlation between informal mechanisms of intimidation, oppression and power on the one hand, and labour mobility on the other. Thus, I argue that plantation labour is by no means passive, yet coerced into passivity and immobility to sustain minimum levels of subsistence. Moving forward, I suggest the need for further empirical research to explain the effects of historically embedded local power relations on the mobility and agency of plantation labour in North Sumatra.

\section{References}

Allain, J. 2015. The Law and Slavery: Prohibiting Human Exploitation. Leiden: Brill Nijhoff. Aspinall, E. 2013. "Popular Agency and Interests in Indonesia's Democratic Transition and

Consolidation." Indonesia 96 (1): 101-102. doi:10.1353/ind.2013.0021.

Aspinall, E., and Fealy, G. 2010. Soeharto's New Order and Its Legacy: Essays in Honour of Harold Crouch. Canberra: ANU E-Press.

Bissonnette, J. 2012. Envisioning Agribusiness: Land, Labour and Value in a Time of Oil Palm Expansion in Indonesia. PhD diss., University of Toronto.

Breman, J. 1989. Taming the Coolie Beast. Oxford: Oxford University Press. 
Breman, J. 2015. Mobilizing Labour for the Global Coffee Market: Profits from an Unfree Work

Regime in Colonial Java. Amsterdam: Amsterdam University Press.

Caraway, T., and Ford, M. 2014. "Labor and Politics under Oligarchy." In Beyond Oligarchy:

Wealth, Power, and Indonesian Politics, edited by Michele Ford and Thomas Pepinsky.

Ithaca, NY: Cornell University Press.

Cribb, R. 2001. "Genocide in Indonesia, 1965-1966." Journal of Genocide Research 3 (2):

219-239. doi:10.1080/14623520123520.

Cumbers, A., C. Nativel, and P. Routledge. 2008. "Labour Agency and Union Positionalities in

Global Production Networks.” Journal of Economic Geography 8 (3): 369-387. doi:10.1093/

jeg/lbn008.

Dunlop, J. T. 1958. Industrial Relations Systems. Michigan: Holt.

Ford, M. 2009. NGOs, Trade Unions, and the Indonesian Labour Movement. Singapore: NUS

Press.

Hadiz, V. R. 2003. "Power and Politics in North Sumatra: The Uncompleted Reformasi." In

Power and Politics in Indonesia: Decentralization and Democratization, edited by E. Aspinall and G. Fealy, 119-131. Singapore: Institute of Southeast Asian Studies.

Hadiz, V. R., and R. Robison. 2013. "The Political Economy of Oligarchy and Reorganization of Power in Indonesia." Indonesia 96 (1): 35-57. doi:10.1353/ind.2013.0023.

Hasibuan, S. 1968. Political Unionism and Economic Development in Indonesia: Case Study, North Sumatra. Berkeley: University of California Press.

Jonker, J., and K. Sluyterman. 2000. At Home on the World Markets: Dutch International Trading Companies from the 16th Century Until the Present. Montreal: McGill-Queen's University Press.

Kahin, A. 1999. Rebellion to Integration: West Sumatra and the Indonesia Polity. Amsterdam: Amsterdam University Press.

Kloosterboer, W. 1960. Involuntary Labour since the Abolition of Slavery: A Survey of Compulsory Labour throughout the World. Leiden: E.J. Brill.

Lane, M. R. 2009. "Mass Mobilisation in Indonesian Politics, 1960 - 2001: Towards a Class Analysis." Thesis collections. Wollongong: University of Wollongong.

Li, T. M. 2014. Land's End: Capitalist Relations on an Indigenous Frontier. Durham, NC: Duke University Press.

Li, T. M. 2015. Social Impacts of Palm Oil in Indonesia: A Gendered Perspective from West Kalimantan. Bogor: Centre for International Forestry Research (CIFOR).

$\mathrm{Li}, \mathrm{T}$. M. 2017. "Intergenerational Displacement in Indonesia's Oil Palm Plantation Zone." The Journal of Peasant Studies 44 (6): 1158-1176. doi:10.1080/03066150.2017.1308353. 
Miers, S. 2003. Slavery in the Twentieth Century: The Evolution of a Global Problem. Oxford: Rowman Altamira. doi:10.1086/ahr/109.3.869-a.

Pelzer, K. J. 1978. Planter and Peasant: Colonial Policy and the Agrarian Struggle in East Sumatra 1863-1947. S-Gravenhage: Martinus Nijhoff.

Poole, M. 1981. Theories of Trade Unionism: A Sociology of Industrial Relations. London: Routledge and Kegan Paul.

Stoler, A. L. 1986. Capitalism and Confrontation in Sumatra's Plantation Belt. $1870-1979$. New Haven, CT: Yale University Press. doi:10.1086/ahr/91.4.978.

Stoler, L. A. 2008. "Imperial Debris: Reflections on Ruins and Ruination." Cultural Anthropology 23 (2): 191-219. doi:10.1111/j.1548-1360.2008.00007.x.

Tornquist, O. 2004. "Labour and Democracy? Reflections on the Indonesian Impasse." Journal of Contemporary Asia 34 (3): 323-377. doi:10.1080/00472330480000171. 